\title{
ENTREPRENEURIAL KNOWLEDGE AND DIGITAL COMPETENCIES - KEYS FOR A SUCCESS OF STUDENTS ENTREPRENEURSHIP
}

\author{
Alina-Andreea Marin* \\ Bucharest University of Economic Studies, Romania \\ E-mail: alina.marin@man.ase.ro

\section{Andreea Chitimiea} \\ Bucharest University of Economic Studies, Romania \\ E-mail: andreea_ch1995@yahoo.com
}

(Received: February 2020; Accepted: April 2020; Published: June 2020)

\begin{abstract}
In today's economy, which is extremely challenging and competitive at the same time, many people want to have their own business and manage their own incomes. Entrepreneurship is a key driver of today's economy. This observation underscores the need to ensure adequate entrepreneurial education, in line with the demands on the labor market. The purpose and role of this experience are to educate students to understand the entrepreneurial activity, to develop their entrepreneurial skills and competencies and the intention to run a business. The learning environment is crucial for a successful entrepreneur and he can generate change. This article describes experiences from developing and using the entrepreneurial learning environment in high schools with a technological profile. In this study 1200 students from three technological high schools were observed, the behavior and the results obtained after studying the specialized economic modules were analyzed. Our goal was to identify the main challenges of these students. In our study, we used a mixed-method: questionnaires, topic-based interviews, direct and participatory observation as data collection methods. According to our results, the main challenges were: difficulties in understanding new entrepreneurial notions due to traditional teaching methods, lack of ICT skills, lack of team learning principles and inefficient communication within a group.
\end{abstract}

Keywords: entrepreneurship, ICT competencies, entrepreneurship education

JEL Codes: L26, I26, P46

*Corresponding author: Alina Andreea Marin.E-mail: alina.marin@man.ase.ro

Copyright (C) 2020 The Author(s). Published by VGWU Press

This is an Open Access article distributed under the terms of the Creative Commons BY 4.0 license (Creative Commons - Attribution 4.0 International - CC BY 4.0) which permits unrestricted use, distribution, and reproduction in any medium, provided the original author and source are credited. 
Marin, A.A., Chitimiea, A., (2020)

Entrepreneurial knowledge and digital competencies - keys for a success of students entrepreneurship

\section{Introduction}

Entrepreneurship is a key driver of today's economy. This observation emphasizes the need for adequate entrepreneurship education in the labor market. The role of this educational line is to educate students to understand the activity of entrepreneurship, to develop their entrepreneurial attitudes and intention to run a business.

The importance of entrepreneurship to society has been identified and discussed since at least the fifteenth century (Schumpeter, 1912), and that discussion remains topical (Kirchhoff et al., 2013; Grichnik \& Harms, 2007).

The promotion of entrepreneurship in Europe has become the main objective of the European Union since 2000 when the Lisbon European Council decided to improve European performance in the following areas: unemployment rate, economic reforms and social cohesion. Subsequently, the European Union started promoting entrepreneurship through the Entrepreneurship 2020 strategy, as this economic process is essential for smart, sustainable and inclusive economic growth.

Promoting entrepreneurship in education as a key competency encourages EU citizens to be enterprising, to find innovative solutions to societal problems and to create products that add socio-economic value.

Entrepreneurship is not only a way of creating jobs, increasing competitiveness and developing the economy, it also contributes to personal fulfillment and social goals.

Education for Entrepreneurship can be seen as one of the contemporary themes of current school and out-of-school education and has also become one of the priority topics of the European Union's education policy.

Entrepreneurial education has as its main objective the stimulation of entrepreneurship in the sense of business initiation and property rights or for the development of entrepreneurial skills.

Entrepreneurial education helps to promote entrepreneurship and innovative culture in Europe by changing thinking and offering skills needed. Teaching entrepreneurship skills through school is a process, and it is highly recommended that students be left free to find their calling through it.

\section{Literature review}

Several researchers have studied, analyzed and defined entrepreneurship. Entrepreneurship is any attempt to set up a new business or a new company, or to develop an existing business or company, by an individual, a group of individuals or a firm (Bosma et al., 2012; Benyovszki et al., 2014). Entrepreneurship is an activity-oriented towards performance and achievements, individuals consuming

58 Sciendo Studia Universitatis "Vasile Goldis" Arad. Economics Series Vol 30 Special Issue 2/2020 ISSN: 1584-2339; (online) ISSN: $2285-3065$

Web: publicatii.uvvg.ro/index.php/studiaeconomia. Pages 57-69 
Marin, A.A., Chitimiea, A., (2020)

Entrepreneurial knowledge and digital competencies - keys for a success of students entrepreneurship

effort for subsequent financial and non-financial rewards. Among the rewards in the second category, we can mention the following: high level of autonomy, job satisfaction, well-being (Hopp \& Stephan, 2012).

In the UK the influential Howard Davies report (Davies, 2002) led the government to the commitment that every child in secondary school should experience at least one week of "Enterprise Education". This project was started to obtain the following results: development of entrepreneurial capacity (skills to discover new ways of doing things, to change things, to evaluate risks, to act efficiently), financial literacy (development of financial skills, management money efficiency, budgetary knowledge, financial planning, risk management), economic and commercial understanding (efficient management of resources, knowledge and understanding of economic terms, decision-making skills, economic judgment).

Entrepreneurship is a way of thinking and subsequently an essential economic process in the new economy, the one based on knowledge, it must be encouraged and sustained because it generates economic development and raising the standard of living. Without education, the participation of young people in cultural and socio-economic life is impossible.

Research on entrepreneurship in later phases of life shows that general education has a long-term impact on the entrepreneurial environment (Hatak et al., 2013, 2015; Harms et al., 2014).

The rate of entrepreneurial activity in the participating GEM countries by regions is presented in the table 1. Total early-stage Entrepreneurial Activity (TEA) is the \% of 18-64 year old population that is either a nascent entrepreneur or owner of a business.

As we can see Early-stage entrepreneurial activity (TEA) owns a percentage of $11.3 \%$.

The aim is to measure two main dimensions: entrepreneurial behavior and attitudes of individuals and the national context.

Table 1 Entrepreneurial activity rates in participating GEM countries by region, 2014 (\% of population aged 18-64 years)

\begin{tabular}{|c|c|c|c|c|}
\hline $\begin{array}{c}\text { Nascent } \\
\text { entrepreneurship } \\
\text { rate }\end{array}$ & $\begin{array}{c}\text { New } \\
\text { business } \\
\text { ownership }\end{array}$ & $\begin{array}{c}\text { Early-stage } \\
\text { entrepreneurial } \\
\text { activity (TEA) }\end{array}$ & $\begin{array}{c}\text { The } \\
\text { established } \\
\text { business } \\
\text { ownership } \\
\text { rate }\end{array}$ & $\begin{array}{c}\text { Discontinuation of } \\
\text { businesses }\end{array}$ \\
\hline 5.3 & 6.2 & 11.3 & 7.6 & 3.2 \\
\hline
\end{tabular}

Source: GEM NES database 2014 
Marin, A.A., Chitimiea, A., (2020)

Entrepreneurial knowledge and digital competencies - keys for a success of students entrepreneurship

"Entrepreneurship involves the: ability to perceive profitable business opportunities, willingness to act on what is perceived and necessary organizing skills associated with a project" (Ekwe, 1992).

Entrepreneurial skills of successful entrepreneurs include:

$>$ Sales and Marketing skills.

$>$ Financial Know-how skills.

$>$ Self-motivation skill.

$>$ Time management skill.

$>$ Administrative skill (Ekwe, 1992).

According to national experts, entrepreneurship education in primary and secondary schools is ranked lower than at the level of high school and vocational and university education in all the countries analyzed from the economies based on efficiency in the European Union in 2014 (Table 2). In Romania, the highest value is recorded in the question regarding the fact that the universities offer good and adequate preparation for the establishment and growth of new companies (3.19), the lowest values are reached in the case of the questions regarding the professional schools and systems, education continues to provide good and adequate preparation for starting and growing new companies (2.25). The table shows the rates in a 1-5 scale (GEM, 2014).

Table 2 Entrepreneurship education in view of the national experts (1-totally disagrees, 5 -totally agrees), 2014

\begin{tabular}{|l|c|c|c|c|c|}
\hline & Romania & Croatia & Hungary & Lithuania & Poland \\
\hline $\begin{array}{l}\text { Teaching in primary and } \\
\text { secondary education } \\
\text { encourages creativity, self- } \\
\text { sufficiency, and personal } \\
\text { initiative }\end{array}$ & 2,40 & 1,82 & 1,94 & 2,58 & 1,72 \\
\hline $\begin{array}{l}\text { Teaching in primary and } \\
\text { secondary education } \\
\text { provides adequate } \\
\text { instruction in market } \\
\text { economic principles }\end{array}$ & 2,33 & 1,72 & 1,69 & 2,44 & 1,80 \\
\hline $\begin{array}{l}\text { Teaching in primary and } \\
\text { secondary education } \\
\text { provides adequate attention } \\
\text { to entrepreneurship and new } \\
\text { firm creation }\end{array}$ & 2,32 & 1,51 & 1,43 & 2,08 & 1,76 \\
\hline $\begin{array}{l}\text { Entrepreneurial level of } \\
\text { education at Primary and } \\
\text { Secondary (summary) }\end{array}$ & $\mathbf{2 , 3 4}$ & $\mathbf{1 , 6 8}$ & $\mathbf{1 , 6 8}$ & $\mathbf{2 , 3 7}$ & $\mathbf{1 , 7 5}$ \\
\hline
\end{tabular}


Marin, A.A., Chitimiea, A., (2020)

Entrepreneurial knowledge and digital competencies - keys for a success of students entrepreneurship

\begin{tabular}{|l|c|c|c|c|c|}
\hline $\begin{array}{l}\text { Colleges and universities } \\
\text { provide good and adequate } \\
\text { preparation for starting up } \\
\text { and growing new firms }\end{array}$ & 3,19 & 2,08 & 2,75 & 3,03 & 2,19 \\
\hline $\begin{array}{l}\text { The level of business and } \\
\text { management education } \\
\text { provides good and adequate } \\
\text { preparation for starting up } \\
\text { and growing new firms }\end{array}$ & 2,58 & 2,75 & 3,21 & 2,97 & 2,35 \\
\hline $\begin{array}{l}\text { The vocational, } \\
\text { professional, and continuing } \\
\text { education systems provide } \\
\text { good and adequate } \\
\text { preparation for starting up } \\
\text { and growing new firms }\end{array}$ & 2,25 & 2,26 & 2,50 & 3,14 & 3,03 \\
\hline $\begin{array}{l}\text { Entrepreneurial level of } \\
\text { education at Vocational, } \\
\text { Professional, College and } \\
\text { University (summary) }\end{array}$ & $\mathbf{2 , 6 8}$ & $\mathbf{2 , 3 5}$ & $\mathbf{2 , 8 2}$ & $\mathbf{3 , 0 7}$ & $\mathbf{2 , 5 4}$ \\
\hline
\end{tabular}

Source: GEM NES database 2014

Many scholars state that there is only one way to learn to become entrepreneurial, and that is by learning through own experience. Cope leans on a variety of scholars (Minniti \& Bygrave, 2001; Dalley \& Hamilton, 2000; Young \& Sexton, 1997; Gibb, 1997) when stating that there seem to be no shortcuts, it "can only be acquired through learning-by-doing or direct observation" (Cope, 2005).

\section{Research methodology}

In this research 1200 students from three technological high schools were observed, the behavior and the results obtained after studying the specialized economic modules were analyzed. Our goal was to identify the main challenges of these students. In our study, we used a mixed-method: questionnaires, topic-based interviews, direct and participatory observation as data collection methods. We started with three hypotheses:

1. The attitudes of students towards entrepreneurship do not change significantly after the completion of the compulsory course of Entrepreneurship Education;

2. The intention of the students to become entrepreneurs is significantly changed after completing the specialized modules, using the virtual platform of the exercise companies and participating in competitions.

3. Students' intention to become entrepreneurs is significantly altered as a result of the acquisition of digital skills. 
Marin, A.A., Chitimiea, A., (2020)

Entrepreneurial knowledge and digital competencies - keys for a success of students entrepreneurship

We used the Pearson correlation coefficient that measures the power and direction of a linear relationship between two variables. The correlations can be positive, as A increases and B increases, or can be negative, as A decreases. Depending on the value of the Pearson correlation coefficient we have the following types of correlations:

Pearson Correlation $<0.3$ - small correlation.

Pearson Correlation between 0.3 and 0.7 - average correlation.

Pearson Correlation $>0.7$ - high correlation.

The greater the belief of the subjects that entrepreneurship education can develop knowledge about the entrepreneurial environment, the greater their desire to continue professional training immediately after graduation, it may be precisely in the entrepreneurial field. On the other hand, the attractiveness of the option to be employed increases as well as the attractiveness of the option of being an entrepreneur; the knowledge gained through entrepreneurship education is not enough to convince the subjects of the superiority of the entrepreneurial career. The subjects do not come into contact with the practical aspects of entrepreneurship. This makes them reluctant and fearful when it comes to their own business.

Increasing the belief of the subjects that specialized modules can develop knowledge and skills about the entrepreneurial environment has made the subjects in these groups more and more eager to set up a business immediately after graduation. The greater the view of the subjects that the specialized modules can develop knowledge, skills and attitudes about the entrepreneurial environment, the greater the determination to do everything to be an entrepreneur and to make every effort to set up and run his own company. The study of the economic modules using the method of the execution companies supports the development of the entrepreneurial competences. The practical aspects encountered in the laboratory hours lead to the rapid development of the key entrepreneurial skills.

According to the statistical data offered by ROCT, the virtual platform The Headquarters of the Network of Exercise Firms / Simulated Enterprises in Romania (ROCT) is a compartment within the National Center for the Development of Vocational and Technical Education. In the 2018-2019 school year, there was a $22.30 \%$ increase of the active companies compared to the 2017-2018 school year. Thus, 1459 exercise companies and simulated enterprises were activated. Growth was in all areas, the highest being in production: $62.89 \%$. From a total of 1459 active companies, a number of 507 companies were new and 952 companies were taken over. In the 2017/2018 school year, 1193 simulated companies were registered and active in ROCT, out of which 235 new companies and 958 companies were taken over (Figure 1).

62 Sciendo Studia Universitatis "Vasile Goldis" Arad. Economics Series Vol 30 Special Issue 2/2020 ISSN: 1584-2339; (online) ISSN: $2285-3065$

Web: publicatii.uvvg.ro/index.php/studiaeconomia. Pages 57-69 
Marin, A.A., Chitimiea, A., (2020)

Entrepreneurial knowledge and digital competencies - keys for a success of students entrepreneurship

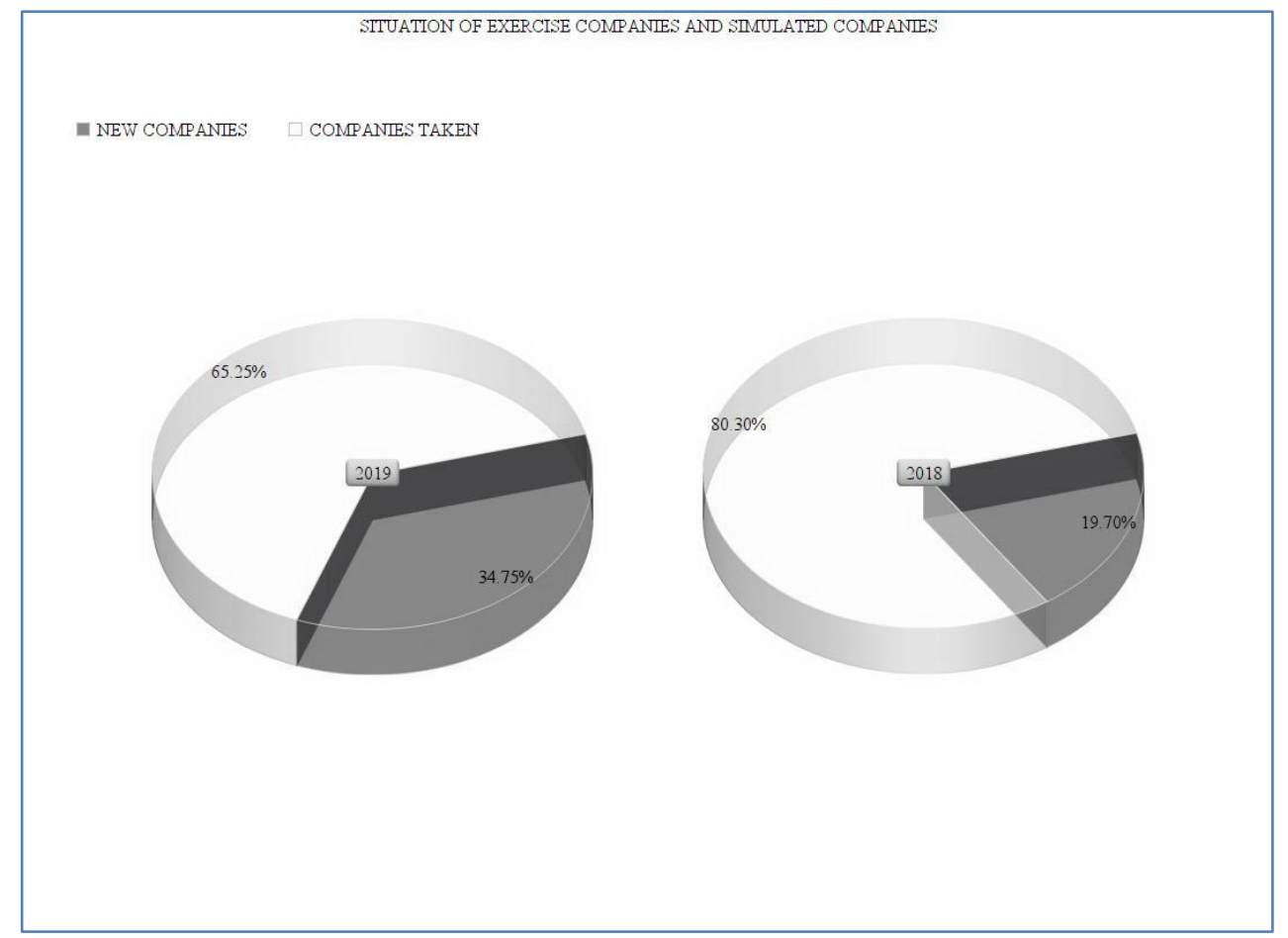

Figure 1 Situation of exercise companies and simulated companies Source: authors' computation based on ROCT data

Exercise companies have the opportunity, starting with 2008, to participate in the Business Plan competition. It was set up to support the entrepreneurial development of the students and to facilitate the correlation of the theoretical training with practical training.

The phases of the competition are local, regional and national. The objectives of the competition are to capitalize on the entrepreneurial spirit, to become familiar with the economic environment, to develop the entrepreneurial skills, to assume the risk, to increase the collaboration between the exercise companies, to encourage competitiveness. Creating a collaborative atmosphere is an indicator of change in education and is also a principle of activating personality reserves.

We analyzed the evolution of the companies participating in the Business Plan competition. 
Marin, A.A., Chitimiea, A., (2020)

Entrepreneurial knowledge and digital competencies - keys for a success of students entrepreneurship

Table 3 Firms participating in the Business Plan competition 2008-2019

\begin{tabular}{|c|c|c|c|}
\hline School year & Local stage & Regional stage & National stage \\
\hline $2008-2009$ & 242 & 65 & 8 \\
\hline $2009-2010$ & 328 & 88 & 8 \\
\hline $2010-2011$ & 364 & 40 & 8 \\
\hline $2011-2012$ & 270 & 64 & 8 \\
\hline $2012-2013$ & 213 & 64 & 9 \\
\hline $2013-2014$ & 379 & 39 & 8 \\
\hline $2014-2015$ & 253 & 38 & 9 \\
\hline $2015-2016$ & 285 & 38 & 8 \\
\hline $2016-2017$ & 322 & 38 & 8 \\
\hline $2017-2018$ & 310 & 34 & 8 \\
\hline $2018-2019$ & 304 & 38 & \\
\hline
\end{tabular}

Source: authors' computation based on ROCT data

We note that in recent years the trend is decreasing, for the local stage. The number of companies participating in the local stage decreased, but not significantly. Although the number of established companies has increased, the number of companies participating in the competition has decreased. Competition is a motivational form of self-assertion, in which the individual competes with others for the attainment of superiority. Superiority in business can only be achieved through cooperation, collaboration. Students who participated in competitions became more confident in their entrepreneurial skills and showed a positive reaction to starting their own business after finishing their studies.

\section{Results and discussion}

Obviously, education will not solve all the problems that humanity faces today, but it is essential in the effort to connect the members of society, to generate new relationships, to respect the demands of the labor market and the needs of the environment.

Entrepreneur education teachers and specialized modules have the capacity of guiding future entrepreneurs not yet occupying a strong place in the academic environment. In a recent meta-analysis, Bae et al. (2014) show that entrepreneurial education, entailing training in the creation of startups, creativity and innovation workshops, as well as the students' entrepre-neural project mentored by the entrepreneurial faculty, increase the intention to start a new business among graduates, even if only a few ever create a company.

Teachers are in the midst of these changes and they have a strong impact on learner performance. They must have the right skills, knowledge and attitudes to provide 
Marin, A.A., Chitimiea, A., (2020)

Entrepreneurial knowledge and digital competencies - keys for a success of students entrepreneurship

students with the new education programs, pedagogies and learning environments they will need to acquire entrepreneurial skills. Teachers are those who play a central role. A school environment is needed where creativity and risk-taking are encouraged, and mistakes are appreciated as an opportunity for learning.

Individuals must continually improve their knowledge and skills in response to the rapid pace of changes that occur every day, otherwise, there will be economic stagnation. Education institutions dealing with vocational training find it difficult, if not impossible, to correlate their ability to adapt education and curricular offer with the pace of changing labor market needs. In a global and dynamic world, it becomes more important for the skills taught in schools to be relevant to the workplace and to be maintained and improved throughout one's professional life. Building a solid foundation of competencies throughout the school years and providing lifelong learning is probably a viable solution to reduce the skills gap.

Entrepreneurial education helps individuals get better jobs, even if they are looking for a job and not for a self-employed activity. Using a multi-level regression, our results indicate a stronger need for entrepreneurial skills training in higher education institutions, on the one hand, and the introduction of policies that promote micro- and macro-level innovation in the countries' economies, other side. Economic modules have become extremely important for several reasons. Learning through exercise companies about developing business plans and setting up a company allows students to better understand and integrate finance, economics, accounting, marketing and other business disciplines, providing them with an engaging and enriching educational experience. After all, entrepreneurship education creates links between the academic and business communities.

Students may not have the best business idea today. But this idea can come over 5, 10,15 years. By that time, these students will already have a knowledge base about entrepreneurship that will allow them to set up what could be the next successful business. Thus investing in our high school students now, we are training the next generation of entrepreneurs for success. This step is very important. And it is much easier to build the foundation. Efforts supported by entrepreneurship education give students the opportunity to see that there is a chance for successful business if they have the necessary skills.

Moreover, entrepreneurship education lowers the risk of being unemployed and increases the chances of people finding it constantly better-paid jobs.

The exercise company represents an interactive learning method for the development of the entrepreneurial spirit, a modern conception of interdisciplinary integration and application of knowledge, an approach of the teaching-learning process that provides conditions for the practical testing and deepening of the skills acquired by students / students in the professional preparation. 
Marin, A.A., Chitimiea, A., (2020)

Entrepreneurial knowledge and digital competencies - keys for a success of students entrepreneurship

The exercise company is a modern teaching method, which aims to develop the entrepreneurial skills of the students by simulating the internal processes carried out in a real firm and its relationships with other companies and institutions. The method simulated enterprises is characterized by two defining aspects:

- Virtual: there is no money and no goods;

- Real: the commercial customs, the flow of information, the documents and the document circuit are respected.

Thus, this method allows the reproduction with different degree of complexity of the processes that is carried out in the real economic activity as well as the transparent representation of these activities for the teaching process. The dynamic, realistic environment of simulated enterprises allows students to achieve many positive results: applying theory in practice, teamwork and communication skills, planning skills and entrepreneurial mentality.

Students need to understand how they can correlate and use and apply different knowledge in diverse contexts, which really means and how they can create synergies between different topics in order to develop / create something that connects to the real world. This brings us to another very important point: students have to work in a project framework and from there they must work with their colleagues, their teachers and the outside world. They must develop new ways of communicating and must be faced with complex situations to develop critical thinking and complex problem solving and to learn how to be imaginative, creative, adaptable, flexible and to develop brain plasticity.

As Alex Gray (2016) says: "Change will not wait for us: business leaders, educators and governments need to be proactive in improving people's qualifications and retraining so that everyone can benefit from the fourth industrial revolution". Therefore, we have the obligation to create models and contexts to enable this, otherwise, we will have a generation without competencies for the new demands of the labor market and which created great problems for society.

\section{Conclusions}

This study shows that the learning environment plays an important role in shaping entrepreneurial skills and developing entrepreneurial skills in students.

In conclusion, after controlling for pre-education entrepreneurial intentions, the relationship between entrepreneurial education and post-education entrepreneurial intentions was not significant.

The results of our survey underline the assumptions that entrepreneurship programs have a positive impact on the development of key skills in the field of entrepreneurship. Students with entrepreneurial skills evaluate their personal entrepreneurial characteristics (sense of initiative, availability at risk, an increase of personal esteem). It also develops its creativity, analysis, motivation, adaptability.

66 Sciendo Studia Universitatis "Vasile Goldis" Arad. Economics Series Vol 30 Special Issue 2/2020 ISSN: 1584-2339; (online) ISSN: 2285 - 3065

Web: publicatii.uvvg.ro/index.php/studiaeconomia. Pages 57-69 
Marin, A.A., Chitimiea, A., (2020)

Entrepreneurial knowledge and digital competencies - keys for a success of students entrepreneurship

The study found that traditional teaching-learning-assessment methods were used by teachers to a large extent. But they neglect critical thinking, problem-solving and decision making. The most common method is lecture. The modern methods of teaching that use the technology are those that motivate the student, increases his creativity level and increases the attractiveness of the course. The research argues that lecturing and memorizing do not help develop entrepreneurial skills and competencies. It has been concluded that traditional training practices have a negative correlation, while modern methods act positively. There is a need for a modern manual that presents to the specialized teachers, effective instructional practices for developing entrepreneurial skills. We concluded that we need: teacher training institutions that have an entrepreneurial vision and strategy; teacher trainers with entrepreneurial spirit: partnerships between the education sector, the business community and the creation-based industry; programs and methods for teacher training in entrepreneurship for students. Thus, the need to raise awareness of entrepreneurial education as a pedagogical approach relevant to all students and at all levels is developed. Special techniques are needed to train entrepreneurial skills in the classroom. Techniques shape the culture of creativity, imagination and innovative thinking in students. It also helps develop the skills of strategic planning, opportunity analysis and identification. Finally, these graduates demonstrate that they have more knowledge about entrepreneurship and the role of entrepreneurs in society.

The motivation for change and the use of entrepreneurial approaches seems to be better in the fields of vocational schools based on intercultural programs such as Information Technology, Civic Education, Economy and Industry.

Future research should compare the effectiveness of the entrepreneurial education in high-schools of the same type as well as across high-schools of different types (e.g. vocational high-schools with economic / business profile versus vocational high-schools).

\section{Acknowledgments}

The authors thank the anonymous reviewers and editor for their valuable contribution.

\section{Funding}

This work was co-financed from the European Social Fund through Operational Programme Human Capital 2014-2020, project number POCU/380/6/13/125015 „Development of entrepreneurial skills for doctoral students and postdoctoral researchers in the field of economic sciences". 


\section{Author Contributions}

The authors designed the study together and were responsible for designing and developing data analysis. They were responsible for data collection and analysis, as well as for data interpretation. A.M. was responsible for the literature review section.

\section{Disclosure Statement}

The authors do not have any competing financial, professional or personal interests from other parties.

\section{References}

1. Benyovszki, A., Nagy, Á., Petru, T.P., (2014), Entrepreneurship in Romania, Country Report 2012, Available online at:

www.gemconsortium.org/docs/download/3253, accessed on 21.02.2020

2. Blank, S.G., Dorf, B., (2012), The startup owner's manual: the step-by-step guide for building a great company, K\&S Ranch, Incorporated

3. Blenker, P., Korsgaard, S., Neergaard, H., Thrane, C., (2011), The questions we care about: paradigms and progression in entrepreneurship education, Industry and Higher Education, 25, 417-427

4. Bosma, N., Schutjens, V., (2011), Understanding regional variation in entrepreneurial activity and entrepreneurial attitude in Europe, Annals of Regional Science, 47 (3), 711-742

5. Cope, J., (2005), Toward a Dynamic Learning Perspective of Entrepreneurship, Entrepreneurship Theory and Practice, 29, 373-397

6. Dalley, J., Hamilton, B., (2000), Knowledge, context and learning in the small business, International Small Business Journal, 18, 51-59

7. Davies, H., (2002), A Review of Enterprise and the Economy in Education, HMSO, UK

8. Ekwe, O.A., (1992), A Structural Adjustment Programme (SAP) - Created Opportunities for Entrepreneurial Development in Nigeria, in Nigerian Structural Adjustment Programme: A Multisectional Analysis: edited by Aham Anyanwu, Enugu, Nigeria ABIC Book \& Equipment

9. Grichnik, D., Harms, R., (2007), Zur Zukunft der deutschsprachigen Entrepreneurshipforschung - Strategien und thematische Schwerpunkte, Zeitschrift für Klein - und Mittelunternehmen und Entrepreneurship 55, 266-275

10. Harms, R., Kraus, S., Luck, F., Walsh, S.T., (2014), On the motivational drivers of gray entrepreneurship: an exploratory study, Technol. Forecast. Soc. Chang. 89, 358-365 
Marin, A.A., Chitimiea, A., (2020)

Entrepreneurial knowledge and digital competencies - keys for a success of students entrepreneurship

11. Hatak, I., Harms, R., Fink, M., (2015), Age, job identification and entrepreneurial intention, Journal of Managerial Psychology, 30(1), 38-53

12. Hatak, I., Kautonen, T., Fink, M., (2013), Senior-Unternehmertum: Empirische Evidenz aus 27 europäischen Ländern, Die Betriebswirtschaft 73, 7-26

13. Johansson-Sköldberg, U., Woodilla, J., Çetinkaya, M., (2013), Design thinking: past, present and possible futures, Creativity and Innovation Management, 22, 121146

14. Kirchhoff, B.A., Linton, J.D., Walsh, S.T., (2013) Neo-Marshallian equilibrium versus Schumpeterian creative destruction: its impact on business research and economic policy, Journal of Small Business Management 51, 159166

15. Minniti, M., Bygrave, W., (2001), A dynamic model of entrepreneurial learning, Entrepreneurship Theory and Practice, 25, 5-16

16. Osterwalder, A., Pigneur, Y., (2010), Business model generation: a handbook for visionaries, game changers, and challengers, John Wiley \& Sons

17. Ries, E., (2010), Lean Startup, New York, Random House Digital

18. Schumpeter, J., (1912), Theorie der Wirtschaftlichen Entwicklung, Duncker \& Humblot, Leipzig

19. Spring, K., Grimm Jr., R., Dietz, N., (2008), Community Service and ServiceLearning in America's Schools, Corporation for National and Community Service 20. Steinke, P., Fitch, P., (2007), Assessing service-learning, Research \& Practice in Assessment, 1, 1-8

21. Young, J.E., Sexton, D.L., (1997), Entrepreneurial learning: a conceptual framework, Journal of Enterprising Culture, 5, 223-48

22. https://www.gemconsortium.org/economy-profiles/romania, Accessed on 21.02.2020

23. http://www.roct.ro/, Accessed on 21.02.2020 